\title{
Early and long-term results of cardiosurgical treatment of coronary artery disease and aortic stenosis in patients over 80 years old
}

\author{
Wiktor Budniak, Piotr Buczkowski, Bartłomiej Perek, Izabela Katyńska, Marek Jemielity \\ Department of Cardiac Surgery and Transplantation, Poznan University of Medical Sciences, Poznan, Poland
}

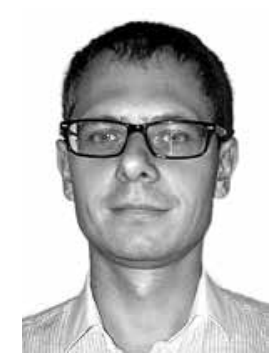

Kardiochirurgia i Torakochirurgia Polska 2014; 11 (3): 246-251

\begin{abstract}
Introduction: In recent years, patients over 80 years of age have been a growing group of individuals referred to cardiac surgeons. They pose a serious challenge and usually require a multidisciplinary approach.

Aim: The aim of this study was to evaluate the early and late outcomes of cardiosurgical treatment of patients over 80 years of age suffering from coronary artery disease and aortic stenosis.

Material and methods: The study involved 96 patients aged over 80 years treated between January, 2004 and December, 2012. The mortality and morbidity in the early postoperative period, as well as throughout the follow-up period, were analyzed.

Results: The majority of patients underwent isolated coronary artery bypass grafting (CABG) (58.3\%; Group I), while $29.2 \%$ of them underwent an isolated aortic valve replacement (AVR) (Group II). Combined procedures (CABG + AVR) were carried out in $12.5 \%$ of patients (Group III). The mean operational risk calculated according to the logistic EuroSCORE was 11.6\%, $11.9 \%$, and 9.5\%, respectively in Group I, Group II and in Group III. In the early postoperative period, 4 patients died (all from Group I). The 30 -day mortality rate was $4.2 \%$ and the morbidity rate was $56.3 \%$. During the post-discharge follow-up period that lasted from 1 to 100 months, 4 patients died (2 from Group I and 2 from Group III). The 2-year probability of survival was $91.9 \pm 3.0 \%$. During the last follow-up clinical assessment, half of the patients were asymptomatic.

Conclusions: The perioperative mortality of the patients is acceptably and markedly lower than that predicted by the logistic EuroSCORE calculator. However, the complication rate, particularly in the early postoperative period, is relatively high. Key words: elderly, cardiac surgery, mortality, outcomes.
\end{abstract}

\section{Streszczenie}

Wstęp: Leczenie chorych powyżej 80. roku życia związane jest z wyższym ryzykiem i niesie ze sobą większe wyzwania ze strony całego personelu medycznego.

Cel: Przedstawienie wczesnych i odległych wyników leczenia kardiochirurgicznego choroby wieńcowej i wady aortalnej u pacjentów powyżej 80. roku życia.

Materiał i metody: Badaną grupę stanowiło 96 chorych w wieku powyżej 80 lat, których w okresie od stycznia 2004 r. do grudnia 2012 r. poddano operacjom kardiochirurgicznym. Analizowano śmiertelność i powikłania zarówno we wczesnym okresie pooperacyjnym, jak i w obserwacji odległej.

Wyniki: Większość chorych poddano bezpośredniej rewaskularyzacji mięśnia sercowego (58,3\%) - grupa I; u 29,2\% chorych wykonano implantację zastawki aortalnej - grupa II. Pacjenci poddani skojarzonemu zabiegowi rewaskularyzacji mięśnia sercowego wraz z implantacją zastawki aortalnej stanowili grupę III (12,5\%). Średnie ryzyko operacyjne obliczone według logistic EuroSCORE wyniosło odpowiednio: dla I grupy - 11,6\%, dla II grupy - 11,9\%, dla III grupy - 9,5\%. Powikłania w okresie pooperacyjnym dotyczyły $56,3 \%$ chorych. Śmiertelność 30-dniowa wyniosła 4,2\%. Były to 4 zgony w grupie I. W obserwacji odległej (wynoszącej średnio 28,2 miesiąca) połowa chorych nie zgłaszała żadnych dolegliwości, zmarło zaś 4 pacjentów (po dwóch z grupy I i III). Dwuletnie prawdopodobieństwo przeżycia dla całej grupy wyniosło $91,9 \pm 3,0 \%$.

Wnioski: Śmiertelność okołooperacyjna u pacjentów powyżej 80. roku życia jest akceptowalna i niższa niż prognozowana na podstawie kalkulatora logistic EuroSCORE. Odsetek powikłań, zwłaszcza we wczesnym okresie pooperacyjnym, jest jednak stosunkowo wysoki. Wyniki leczenia kardiochirurgicznego tych chorych są dobre, aczkolwiek jest to grupa pacjentów wymagająca szczególnej opieki około- i pooperacyjnej.

Słowa kluczowe: podeszły wiek, leczenie kardiochirurgiczne, śmiertelność, wyniki. 


\section{Introduction}

The aging of the human population and easier access to diagnostic tests contribute to patients over 80 years of age constituting a growing group of individuals referred for cardiac surgical procedures. Due to the age itself, significantly deprived organ reserves, and - not uncommonly - many concomitant disorders, the elderly pose a serious challenge and usually require a multidisciplinary approach. The postoperative course of the elderly patients is more challenging. In spite of the fact that sophisticated techniques such as intra-aortic balloon pump (IABP) or continuous venovenous hemofiltration (CVVH) are applied more frequently and more drugs are administered (blood products, inotropic agents, broad spectrum antibiotics), elderly patients usually stay longer at the intensive care units and are hospitalized longer. Therefore, the total cost of cardiac surgical procedures are markedly higher for the elderly than for younger individuals. To reduce the mortality and morbidity rate, advanced surgical techniques, such as less invasive procedures, and specific materials that can shorten the operating time are more frequently employed in cardiac surgical departments [1-3].

\section{Aim of the study}

The aim of the study was to analyze the early and late outcomes of cardiac surgical treatment of patients over 80 years of age suffering from a coronary artery disease and aortic valve stenosis.

\section{Material and methods}

This study involved 96 patients, including 28 women (29\%) and 68 men (71\%) over 80 years of age, who underwent a cardiac surgical operation between January 2004 and December 2012 (Fig. 1). The mean age of the enrolled patients was $80.8 \pm 2.1$ years (range from 80 to 89 years of age). The clinical data of patients with special attention to preexisting comorbidities and types of cardiac surgical procedures are presented in Table I.

In all patients, during hospitalization, in the pre- and postoperative periods, laboratory tests, physical examinations and additional tests such as EKG, chest X-ray, echocardiography as well as other laboratory tests were routinely performed. The operational risk was calculated according to the logistic EuroSCORE.

Some operations were performed using extracorporeal circulation (ECC) with routine cannulation of the ascending aorta and the right atrium using a cannula of common vein flow. In order to protect the myocardium, cold crystalloid cardioplegia was given to the aortic bulb or directly into the coronary vasculature roots, in accordance with the St. Thomas Hospital procedure. The remaining patients underwent off pump coronary artery bypass (OPCAB) procedures, using an Octopus III operating field stabilization system and ClearView intracoronary shunts. In 11 patients with aortic defects, with accompanying contraindications to classic operational cardiac surgery, a transcutaneous aortic valve implantation (TAVI) was performed.

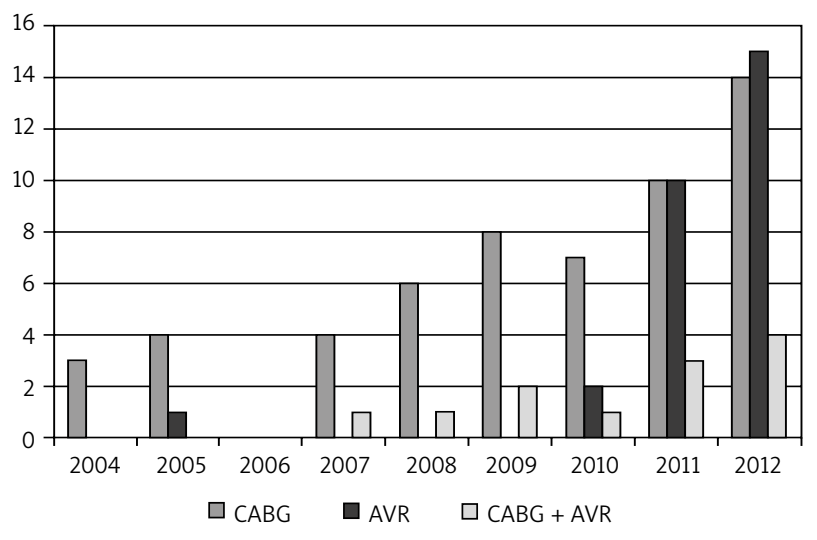

CABG - coronary artery bypass grafting, AVR - aortic valve replacement

Fig. 1. Numbers of patients operated on in consecutive years $(n=96)$

Tab. I. Baseline characteristics of patients undergoing cardiac surgery

\begin{tabular}{|c|c|c|c|}
\hline All patients, $n=96(100 \%)$ & CABG, $n=56(58.3 \%)$ & $\begin{array}{c}\text { AVR, } n=28(29.2 \%) \\
\text { (with TAVI, } n=11 \text { ) }\end{array}$ & CABG + AVR, $n=12(12.5 \%)$ \\
\hline Age $^{*}$ (years) $-80.8 \pm 2.1$ & $80.6 \pm 1.8$ & $81.7 \pm 2.5$ & $80.2 \pm 1.7$ \\
\hline Gender (women) - 28 (29\%) & $23.2 \%$ & $42.8 \%$ & $25 \%$ \\
\hline Arterial hypertension - 58 (60.4\%) & $67.8 \%$ & $50 \%$ & $50 \%$ \\
\hline Diabetes - 31 (32.3\%) & $37.5 \%$ & $28.5 \%$ & $16.7 \%$ \\
\hline Chronic renal failure - 26 (27.1\%) & $21.4 \%$ & $46.4 \%$ & $8.3 \%$ \\
\hline Atrial fibrillation - 11 (11.5\%) & $8.9 \%$ & $17.8 \%$ & $8.3 \%$ \\
\hline Stroke - 9 (9.4\%) & $12.5 \%$ & $7.1 \%$ & 0 \\
\hline COPD - $6(6.3 \%)$ & $5.4 \%$ & $7.1 \%$ & $8.3 \%$ \\
\hline $\operatorname{LVEF}^{\star}(\%)-53.9 \pm 11.4$ & $51.7 \pm 12.7$ & $57.3 \pm 7.1$ & $56.4 \pm 11.8$ \\
\hline Logistic EuroSCORE*(\%) - $11.5 \pm 7.9$ & $11.6 \pm 6.8$ & $11.9 \pm 4.5$ & $9.5 \pm 4.1$ \\
\hline
\end{tabular}


All patients discharged from the hospital were systematically studied in the outpatient cardiac surgery clinic. During each visit, the patient's history and physical examination were performed, together with EKG and, in selected cases, echocardiography. Moreover, the functional status was classified according to the NYHA (New York Heart Association) system. The patient's postoperative course analysis was focused primarily on the assessment of postsurgical improvement, the assessment of physical exercise tolerance, and the registration of occurring cardiac incidents such as myocardial infarction, arrhythmia, and repeated cardiac interventions, including percutaneous coronary interventions $(\mathrm{PCI})$. Neurological events such as transient ischemic attacks (TIA) and brain strokes were also assessed.

\section{Statistical analysis}

Mortality and morbidity in the early postoperative period as well as throughout the follow-up period were analyzed. The probability of survival was calculated using Kaplan-Meier curves (for the entire population and particular groups). Continuous variables are presented as means \pm standard deviations. Statistical significance of $p<0.05$ was assumed for all statistical data. Statistical analysis was performed using Statistica.

\section{Results}

The average operation risk of all studied patients, calculated according to the logistic EuroSCORE system, was 11.5 $\pm 7.9 \%$. The detailed operating risk for particular groups was $11.6 \pm 6.8 \%, 11.9 \pm 4.5 \%$, and $9.5 \pm 4.1 \%$ for CABG, AVR, and AVR + CABG groups, respectively.

In our trial group, the main indication for surgery was coronary artery disease and the most commonly performed cardiac surgical procedure was CABG $(n=56 ; 58.3 \%)$. Within this group, 14 patients were operated on using ECC and the remaining ones ( $n=42 ; 75 \%)$ on the beating heart (OPCAB). In 1 patient, diagnosed with coronary artery dis- ease and symptomatic aortic stenosis, porcelain ascending aorta was the reason that only no-touch aorta CABG was performed. The average number of grafts was $1.9 \pm$ 0.7 per patient. In $95.6 \%$ of cases, the left internal mammary artery (LIMA) was used, while in $72.0 \%$ of cases, the saphenous vein was used. The most frequently revascularized coronary artery was the left anterior descending (LAD) artery. The second most common indication for surgery was symptomatic aortic stenosis ( $n=28 ; 29.2 \%)$. In the remaining patients $(n=12 ; 12.5 \%)$, combined procedures of CABG and AVR were carried out.

In the group of patients $(n=40)$ in which an aortic prosthesis valve was placed, a biological prosthesis valve was implanted (C-E Perimount of 21, 23 and $25 \mathrm{~mm}$ in size) in 34 cases $(85 \%)$. In the remaining aortic valve implantation procedures, mechanical valves were used (ONX of 19 and $21 \mathrm{~mm}$ in size). Eleven patients were treated with TAVI. In the procedures using femoral access, a Medtronic CoreValve 26 or $29 \mathrm{~mm}$ prosthesis valve was implanted.

\section{In-hospital period}

The 30-day mortality rate of the studied group was $4.2 \%$; it was slightly higher in the CABG group $(7.1 \%$; 2 cases in ECC and 2 more in OPCAB). The death of 3 patients was caused by acute kidney failure and multiorgan system failure. One patient died on the $5^{\text {th }}$ day due to hemodynamic instability that resulted from hemorrhagic shock.

The average postoperative hospital stay was $12.6 \pm 6.4$ days, whereas the average stay in the intensive postoperative care unit was $4.3 \pm 4.3$ days. The average postoperative drainage was $936 \pm 645 \mathrm{ml}$, while the mean intubation time was $10.3 \pm 4.7 \mathrm{~h}$. In the perioperative period, each patient was infused with an average of $3.1 \pm 2.2$ units of packed red blood cells and $1.6 \pm 1.7$ units of fresh frozen plasma.

Early postoperative events were observed in 54 patients (56.3\%). The most frequent postoperative complications are presented in Table II. The most frequently recorded

Tab. II. Most frequent perioperative complications

\begin{tabular}{|c|c|c|c|}
\hline$n=96(100 \%)$ & CABG $(n=56)$ & AVR $(n=28)$ & CABG + AVR $(n=12)$ \\
\hline Atrial fibrillation - 35 (36.5\%) & $46.4 \%$ & $14.3 \%$ & $41.7 \%$ \\
\hline Low cardiac output - 7 (7.3\%) & $10.7 \%$ & $3.6 \%$ & 0 \\
\hline Third degree atrioventricular block - 1 (1.04\%) & 0 & 0 & $8.3 \%$ \\
\hline Prolonged mechanical ventilation - 6 (6.3\%) & $8.9 \%$ & 0 & $8.3 \%$ \\
\hline Pneumothorax - 4 (4.2\%) & $1.8 \%$ & $7.1 \%$ & $8.3 \%$ \\
\hline Acute renal failure - 15 (15.6\%) with CVVH - 8 (8.3\%) & $16 \%, 8.9 \%$ & $10.7 \%, 3.6 \%$ & $25 \%, 16.7 \%$ \\
\hline Post-surgical psychosis - 7 (7.3\%) & $12.5 \%$ & 0 & 0 \\
\hline Stroke - $1(1.04 \%)$ & 0 & $3.6 \%$ & 0 \\
\hline Acute abdomen - 3 (3.1\%) & $1.8 \%$ & 0 & $16.7 \%$ \\
\hline Sternal instability - 3 (3.1\%) & $3.6 \%$ & $3.6 \%$ & 0 \\
\hline Mortality - 4 (4.2\%) & $7.1 \%$ & 0 & 0 \\
\hline
\end{tabular}

CABG - coronary artery bypass grafting, AVR - aortic valve replacement, CVVH - continuous veno-venous hemofiltration 
atrial fibrillation was successfully treated with a continuous infusion of amiodarone. Low cardiac output syndrome was treated with IABP for a few days. One patient required the implantation of a DDD pacemaker because of complete AV block. Patients with respiratory insufficiency required prolonged mechanical ventilation (over 12 hours). Pneumothorax was treated with suction drainage of the pleura left in place for at least 48 hours. Due to increasing symptoms of renal insufficiency (creatine concentration above $200 \mu \mathrm{mol} / \mathrm{L}$, oliguria), CVVH was employed in 8 patients (8.3\%). In 3 cases (3.1\%), symptoms of acute abdomen qualified the patients for surgical intervention. In 1 patient, exploratory laparoscopy was performed, while in another patient laparotomy was carried out and a hydrocele of the gall bladder was removed. In yet another patient, laparotomy was performed and diffuse intestinal necrosis was diagnosed. Infection of the sternotomy wound with sternal instability requiring reoperation was noted in 3 patients. Patients who developed post-operative delirium presented with disorientation to time and place, as well as mental agitation which required the administration of psychotropic medication.

\section{Late follow-up}

The mean length of follow-up was $28.2 \pm 27.3$ months (from 1 to 100 months after the cardiac surgery), and 3 patients were not lost to follow-up. The attached figures present the probability of survival of the entire study population, including patients who underwent CABG and patients who underwent simultaneous combined operations (AVR + CABG) using the Kaplan-Meier method (Figs. 2-4). However, in late follow-up, the two-year probability of survival for the entire group was $91.9 \pm 3.0 \%$.

More than half of the patients manifested significant improvement in their functional status and remained asymptomatic during the follow-up period. At the end of the follow-up, three-fourths of the patients were included

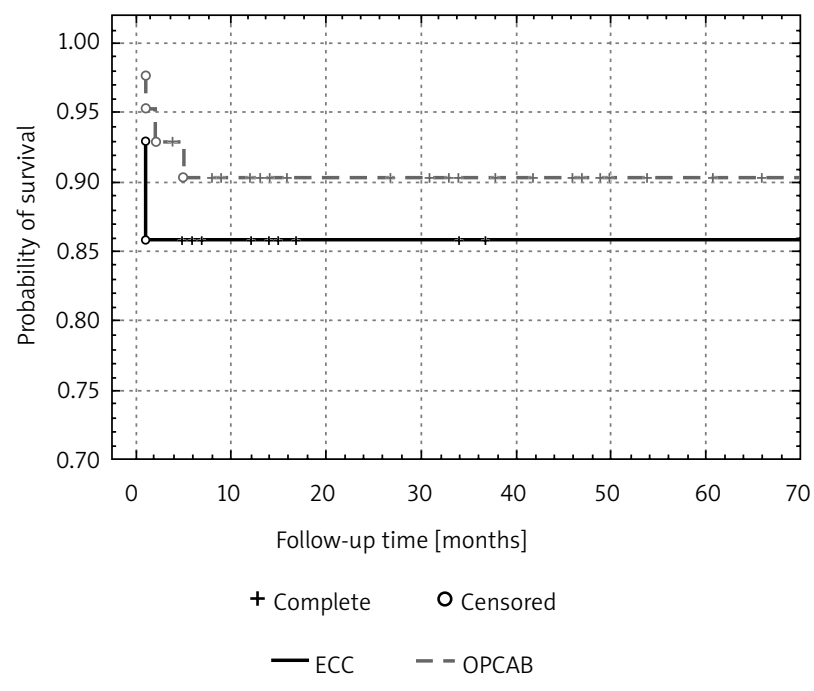

ECC - extracorporeal circulation, OPCAB - off pump coronary artery bypass

Fig. 3. Probability of survival determined by the Kaplan-Meier method for the CABG group (in ECC + OPCAB) (Wilcoxon test according to Gehan: $p=0.57$ )

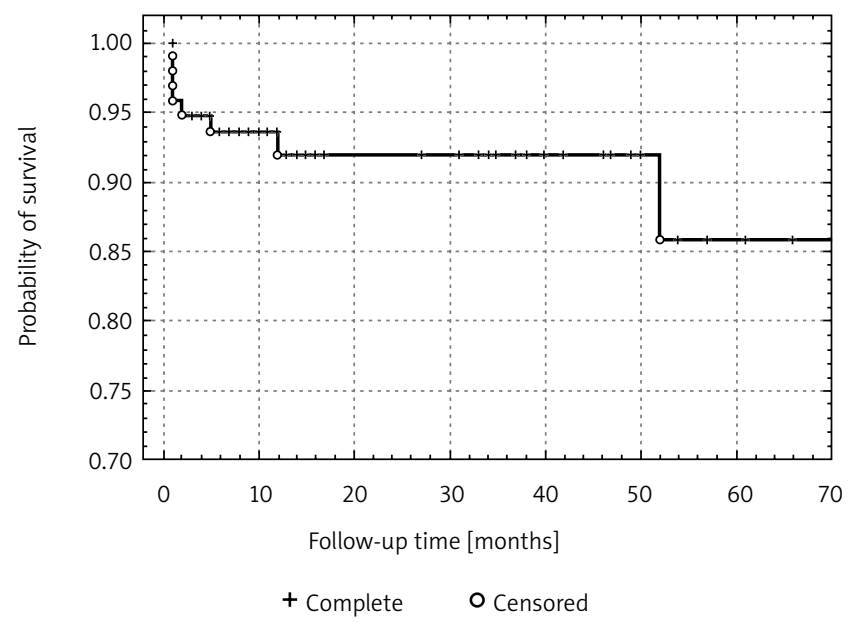

Fig. 2. Probability of survival determined by the Kaplan-Meier method for the entire study group

in NYHA functional classes I and II. The most frequently observed complications were cardiac events (including acute coronary syndrome treated with $\mathrm{PCl}$ ) and brain strokes. The late mortality rate was $4.5 \%$ (4 deaths) (Table III).

\section{Discussion}

The number of hospitalized elderly patients grows with each year. This steady trend has been confirmed by the experience of our department. Over the last eight consecutive years, the number of elderly patients who underwent cardiac surgical procedures has been increasing and reached the largest volume in 2012. It is directly linked with the aging of society, as well as advances in diagnostic tools. Due to the progress in the methods used in cardiac surgery and postoperative intensive care in recent years, cardiac surgical operations can be performed relatively safely in patients over the age of 80 . However, it is necessary to bear in mind that they still constitute a group of patients who require special pre- and postoperative care. Advanced primary dis-

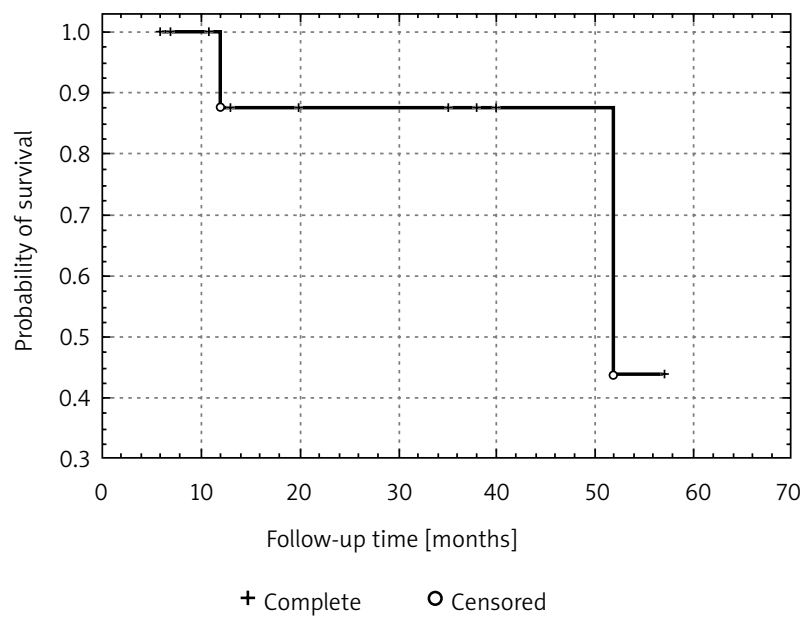

CABG - coronary artery bypass grafting, AVR - aortic valve replacement

Fig. 4. Probability of survival determined by the Kaplan-Meier method for the AVR + CABG group 
Tab. III. Patient's characteristics in the follow-up

\begin{tabular}{lccc}
$n=89(100 \%)$ & CABG $(n=52)$ & AVR $^{*}(n=25)$ & CABG + AVR $(n=12)$ \\
NYHA I - $47(53 \%)$ & $52 \%$ & $52 \%$ & $58.3 \%$ \\
\hline NYHA II - $15(16.8 \%)$ & $19.2 \%$ & $16 \%$ & $8.3 \%$ \\
\hline NYHA III - 6 (6.7\%) & $7.7 \%$ & $8 \%$ & 0 \\
\hline NYHA IV - & 0 & 0 & 0 \\
\hline Cardiac events - 14 (15.7\%) (with PCI - 8) & $17.3 \%(3)$ & $8 \%(4)$ & $8.3 \%(1)$ \\
\hline Stroke - 3 (3.4\%) & 0 & 0 & $8.3 \%$ \\
\hline Mortality - $4(4.5 \%)$ & $3.8 \%$ & $16.7 \%$ \\
\hline
\end{tabular}

*3 patients were lost.

CABG - coronary artery bypass grafting, AVR - aortic valve replacement, $\mathrm{PCl}$ - percutaneous coronary interventions, NYHA - New York Heart Association

eases, older age, and numerous comorbidities not only contribute to the occurrence of complications, but also present postoperative challenges, including rehabilitation $[4,5]$.

In comparison to younger patients, the mortality of elderly patients is higher. This results from deprived organ reserves and many concomitant disorders [5-7]. Perioperative mortality in our trial group was $4.2 \%$. It is comparable (or lower) to the findings of the previously published reports and much lower than the prognostic values of logistic EuroSCORE [6, 8-10]. In the long-term follow-up (up to 100 months), a significant clinical improvement was observed $[11,12]$.

Coronary disease is one the most commonly found ailments in patients over 80 years of age. We have adopted a strategy to operate on elderly CABG patients without the use of ECC (OPCAB). This modification is less invasive than the traditional approach, but still achieves a desirable effect $[7,8,13]$. About $75 \%$ of patients in this study were treated without ECC.

Due to degeneration with age, severe and symptomatic aortic stenosis is characteristic in this group of patients. In $85 \%$ of patients, biological valvular prostheses were implanted (except for patients with chronic atrial fibrillation, who had mechanical prostheses implanted). The gold standard is the use of bioprostheses in the older population. This is connected with the lack of lifelong anticoagulation therapy, thus reducing the risk of bleeding and thromboembolic events [11]. In 11 patients, TAVI therapy was used (introduced in our department at the end of 2010). This method has become a more common approach in high-risk patients with contraindications to the classical treatment [1].

The morbidity rate in this study was $56.3 \%$ (54 patients). The most common complications included atrial fibrillation, renal failure, psychosis, and respiratory failure. Hence the need for longer hospitalization and more intensive or additional therapy, such as prolonged mechanical ventilation (over 12 hours), dialysis (CVVH), IABP, transfusions, and prolonged rehabilitation, which adds to the cost and delays recovery $[5-7,11,14]$.

A disturbing complication is infection of the sternal wound. Despite the use of wide-spectrum antibiotics, an infection can require revision surgery. In elderly patients with decreased immunity, advanced osteoporosis, mineral malabsorption, anemia, and diabetes, the healing of the sternum can be complicated. For this reason, accurate hemostasis, modified reosteosynthesis with wires, and the placement of a gentamycin impregnated sponge within the sternum are all employed. These measures have become standard in patients over the age of 70 , as well as patients with diabetes and obesity [15-17].

Elderly patients with significantly deprived organ reserves and, not uncommonly, many concomitant disorders are often exposed to complications. This results in longer hospitalization, including rehabilitation, and - consequently - higher costs. In this situation, taking into account the higher risk of mortality and morbidity, alternative treatments can be offered, such as less invasive procedures (OPCAB, MIDCAB, TAVI, PTCA) or modified and intensified pharmacotherapy $[1-3,6,12,18]$.

\section{Conclusions}

The perioperative mortality of patients over 80 years of age is acceptable and markedly lower than that predicted by the logistic EuroSCORE calculator. However, the complication rate, particularly in the early postoperative period, is relatively high compared to younger patients. With the optimal selection of therapy and by employing an interdisciplinary approach, it is possible to achieve good early and late outcomes.

\section{Disclosure}

The authors report no conflict of interest.

\section{References}

1. Kowalczuk A, Herdyńska-Wąs M, Foremny J, Przybylski R, Kucewicz E, Zembala M. Leczenie kardiochirurgiczne chorych w wieku podeszłym - wyzwanie, ale i sprawdzian dla leczących. Kardiologia na co Dzień 2010; 3: 90-92.

2. Jemielity M, Perek B. Kardiochirurgia u chorych w wieku podeszłym. Gerontol Pol 2003; 2: 109-114.

3. Kanalikova K. Cardiac surgery in the elderly from the point of cardiologist. Evaluation of risk and outcome. Bratisl Lek Listy 2001; 102: 473-478.

4. Easo J, Holzl PP, Horst M, Dikov V, Litmathe J, Dapunt O. Cardiac surgery in nonagenarians: pushing the boundary one further decade. Arch Gerontol Geriatr 2011; 53: 229-232. 
5. Alexander KP, Anstrom KJ, Muhlbaier LH, Grosswald RD, Smith PK, Jones RH, Peterson ED. Outcomes of cardiac surgery in patients age 80 years: results from the national cardiovascular network. JACC 2000; 35: 731-738.

6. Matt P, Bernet F, Grapow M, Zerkowski HR. Cardiac surgery in elderly patients: what is the evidence? Heart Drug 2004; 4: 119-122.

7. Rodriguez R, Torrents A, Garcia P, Ribera A, Permanyer G, Moradi M, Dous set $P$, Igual A, Murtra M. Cardiac surgery in elderly patients. Rev Esp Cardiol 2002; 55: 1159-1168

8. Perek B, Jemielity M, Stachowiak W, Misterski M, Dyszkiewicz W. Wczesne i odległe wyniki chirurgicznej rewaskularyzacji mięśnia sercowego u chorych po 70. roku życia. Gerontologia Pol 2003; 2: 131-135.

9. Valle FH, Costa AR, Pereira EM, Santos EZ, Pivatto Junior F, Bender LP, Trombka M, Modkovski TB, Nesralla IA, Kalil RA. Morbidity and mortality in patients aged over 75 years undergoing surgery for aortic valve replacement. Arq Bras Cardiol 2010; 94: 720-725.

10. Krane M, Voss B, Hiebinger A, Deutsch MA, Wottke M, Hapfelmeier A, Badiu CC, Bauernschmitt R, Lange R. Twenty years of cardiac surgery in patients aged 80 years and older: risks and benefits. Ann Thorac Surg 2011; 91: 506-513.

11. Kohl P, Kerzmann A, Lahaye L, Gerard P, Limet R. Cardiac surgery in octogenarians. Peri-operative outcome and long-term results. Eur Heart J 2001; 22: 1235-1243.
12. Fruitman DS, MacDougall CE, Ross DB. Cardiac surgery in octogenarians: can elderly patients benefit? quality of life after cardiac surgery. Ann Thorac Surg 1999; 68: 2129-2135.

13. Serrao M, Graca F, Rodrigues R, Abecasis M, Bruges L, Calquinha J, Neves J, Bebocho MJ, Ferreira M, Queiroz e Melo J. Coronary artery bypass grafting in octogenarians: long-term results. Rev Port Cardiol 2010; 29: 989-998.

14. Scott BH, Seifert FC, Grimson R, Glass PS. Octogenarians undergoing coronary artery bypass graft surgery: resource utilization, postoperative mortality and morbidity. J Cardiothorac Vasc Anesth 2005; 19: 583-588.

15. Sakamoto H, Fukuda I, Oosaka M, Nakata H. Risk factors treatment of deep sternal wound infection after cardiac operation. Ann Thorc Cardiovasc Surg 2003; 9: 226-232.

16. Canadyova J, Kurfirst V, Mokracek A. Use of gentamicin-collagen sponges prior to sternal closure may lower the risk of sternal wound infection: a single center experience. Kardiochir Torakochir Pol 2012; 9: 415-419.

17. Friberg O, Svedjeholm R, Söderquist B, Granfeldt H, Vikerfors T, Källman J. Local gentamicin reduces sternal wound infection after cardiac surgery: a randomized controlled trial. Ann Thorac Surg 2005; 79: 153-162.

18. Bochenek A, Skarysz J. Operacje u chorych w starszym wieku. In: Zembala M, Bochenek A, Woś S (eds.). Chirurgia naczyń wieńcowych. Wyd. Lekarskie PZWL, Warszawa 2002; 322-325. 